\title{
Organic Fertilizer Comparison on Growth and Nutrient Content of Three Kale Cultivars
}

\author{
Natalie Yoder ${ }^{1}$ and Jessica G. Davis ${ }^{1}$
}

\begin{abstract}
Additional Index wORDs. Brassica, cyanobacteria, fish emulsion, iron, nitrogen, organic soil fertility, zinc

SUMMARY. Selecting supplemental nitrogen $(\mathrm{N})$ fertilizer for use on certified organic farms can be difficult and confusing. There are many options commercially available to farmers with similar $\mathrm{N}$ concentrations but widely different ingredients. Experiments were conducted in a certified organic field and high tunnels near Fort Collins, $\mathrm{CO}$ in 2013 and 2014 to evaluate the impact of organic fertilizers on yield and nutrient concentrations of three kale (Brassica olevacea and Brassica napus) cultivars. This study includes an organic fertilizer (cyano-fertilizer), which is produced on-farm by growing $\mathrm{N}$-fixing cyanobacteria (Anabaena cylindrica) in raceway ponds. The three fertilizer treatments were hydrolyzed fish emulsion, alfalfa (Medicago sativa) meal, and cyano-fertilizer. These were applied at rates calculated by subtracting soil nitrate concentration from a target $50 \mathrm{mg} \cdot \mathrm{kg}^{-1}$ to the depth of 6 inches of soil. Cyano-fertilizer and hydrolyzed fish emulsion were applied in liquid form, while the alfalfa meal was incorporated dry into the soil before planting. Biweekly measurements of plant height were taken on three cultivars of kale: Dinosaur, Red Russian, and Winterbor. Leaf weight, leaf area, and N, iron (Fe), and zinc $(\mathrm{Zn})$ concentrations were measured during three to four monthly harvests each year. Organized in a split-plot experimental design, there were three treatment replications with subplots of different kale cultivars. Fertilizer treatment did not significantly affect plant height, leaf weight, leaf area, or plant $\mathrm{N}$, Fe, and $\mathrm{Zn}$ concentrations. However, there were cultivar differences in plant height, leaf area, and yield. Kale cultivar choice had a larger impact on yield and plant nutrient concentrations than fertilizer choice, because fertilizers were applied at similar $\mathbf{N}$ rates.
\end{abstract}

$\mathrm{N}$ itrogen $(\mathrm{N})$, a limiting nutrient in all agricultural systems, can be difficult to manage in certified organic vegetable production. Organic agriculture relies heavily on fertilizers and soil amendments from off-farm sources such as fish emulsion, blood meal, feather meal, alfalfa (Medicago sativa) meal, compost, and animal manures (Gaskell et al., 2006) for soil fertility and crop nutrients. The use of supplemental fertilizers is so common that the marketplace is now inundated with variations of these organic $\mathrm{N}$ options, but there is little research comparing their true impacts on plant growth

Received for publication 9 Aug. 2019. Accepted for publication 13 Jan. 2020.

Published online 17 February 2020.

${ }^{1}$ Department of Horticulture and Landscape Architecture, Colorado State University, Fort Collins, CO 80523-1173

N.Y. is a Research Associate.

J.G.D. is Department Head.

J.G.D. is the corresponding author. E-mail: jessica. davis@colostate.edu.

This is an open access article distributed under the CC BY-NC-ND license (https://creativecommons.org/ licenses/by-nc-nd/4.0/).

https://doi.org/10.21273/HORTTECH04483-19 and quality (Hartz and Johnstone, 2006).

Organic $\mathrm{N}$ fertilizers are usually found in two forms, solid and liquid. Solid fertilizers are often incorporated into the soil before planting, while liquid fertilizers are generally applied post planting and are frequently applied season-long through irrigation systems. All these organic materials are rich in slow-releasing organic $\mathrm{N}$, and the mineralization rate is difficult to predict when planning to meet crop uptake needs. In a 2006 study by Hartz and Johnstone, fish powder, blood meal, and feather meal were all found to have very high levels of organic N $(93 \%$ to $99 \%$ of total N was in organic form). These fertilizer types rely on soil microbes to convert organic $\mathrm{N}$ into inorganic $\mathrm{N}$ forms such as ammonium $\left(\mathrm{NH}_{4}^{+}\right)$and nitrate $\left(\mathrm{NO}_{3}{ }^{-}\right)$before plant uptake (Gaskell and Smith, 2007). Therefore, organic fertilizers are less predictable than conventional fertilizers, and while there is an abundance of literature on manure and compost use in the field, little research has been done comparing supplemental organic $\mathrm{N}$ fertilizers.

Most organic fertilizers are produced off-farm and distributed widely throughout the United States. Fish emulsions are produced as a byproduct of the seafood industry and often traded internationally (Soares et al., 1973). The fish hydrolysate used in this study (Neptune's Harvest) is produced in Gloucester, MA and shipped in a concentrated liquid form (it journeyed $\approx 1900$ miles to the location of this study). Because these liquid fish fertilizers are affordable, relatively fast acting, and easy to apply, farmers are encouraged to rely on outside sources for the additional $\mathrm{N}$ needed during the growing season and to pay the extra cost of shipping heavy liquids around the United States. However, there are new fertilizer options being developed that allow farmers to produce $\mathrm{N}$ on-farm. This study includes one such fertilizer, cyanobacteria-based, to compare with off-farm sources.

Cyanobacteria (formerly known as blue-green algae) have been documented as a source of $\mathrm{N}$ in rice (Oryza

\begin{tabular}{llll}
\hline $\begin{array}{l}\text { Units } \\
\begin{array}{l}\text { To convert U.S. } \\
\text { to SI, multiply by }\end{array}\end{array}$ & U.S. unit & SI unit & $\begin{array}{l}\text { To convert SI to } \\
\text { U.S., multiply by }\end{array}$ \\
\hline 0.4047 & acre $(\mathrm{s})$ & $\mathrm{ha}$ & 2.4711 \\
29.5735 & $\mathrm{fl} \mathrm{oz}$ & $\mathrm{mL}$ & 0.0338 \\
0.3048 & $\mathrm{ft}$ & $\mathrm{m}$ & 3.2808 \\
3.7854 & $\mathrm{gal}$ & $\mathrm{L}$ & 0.2642 \\
9.3540 & gal/acre & $\mathrm{L} \cdot \mathrm{ha}^{-1}$ & 0.1069 \\
2.54 & inch $(\mathrm{es})$ & $\mathrm{cm}$ & 0.3937 \\
6.4516 & inch & $\mathrm{cm}$ & 0.1550 \\
1.1209 & $\mathrm{lb} / \mathrm{acre}$ & $\mathrm{kg} \cdot \mathrm{ha}^{-1}$ & 0.8922 \\
0.1198 & $\mathrm{lb} / \mathrm{gal}$ & $\mathrm{kg} \cdot \mathrm{L}^{-1}$ & 8.3454 \\
0.0254 & $\mathrm{mil}(\mathrm{s})$ & $\mathrm{mm}$ & 39.3701 \\
1 & $\mathrm{mmho} / \mathrm{cm}$ & $\mathrm{dS} \cdot \mathrm{m}^{-1}$ & 1 \\
28.3495 & $\mathrm{oz}$ & $\mathrm{g}$ & 0.0353 \\
1 & $\mathrm{ppm}$ & $\mathrm{mg} \cdot \mathrm{kg}^{-1}$ & 1 \\
2.2417 & ton $(\mathrm{s}) / \mathrm{acre}$ & $\mathrm{t} \cdot \mathrm{h}^{-1}$ & 0.4461 \\
$\left({ }^{\circ} \mathrm{F}-32\right) \div 1.8$ & ${ }^{\circ} \mathrm{F}$ & ${ }^{\circ} \mathrm{C}$ & $\left({ }^{\circ} \mathrm{C} \times 1.8\right)+32$ \\
& & &
\end{tabular}


Table 1. Field soil test results from composited samples representing kale research sites at Colorado State University, Fort Collins. Research sites were used to study organic fertilizer comparison on growth and nutrient content of kale in high tunnels (tunnel 4, tunnel 5, and tunnel 6) in 2013 and in the field in 2014. Soil pH and electrical conductivity (EC) were measured in saturated past extracts. Organic matter $(O M)$ was measured through loss on ignition, and nutrients were analyzed in ammonium bicarbonate-diethylenetriaminepentaacetic acid (AB-DTPA) extracts. Multiple samples were mixed together for a single submitted sample for each site.

\begin{tabular}{|c|c|c|c|c|c|c|c|c|c|c|}
\hline \multirow[b]{2}{*}{$\underline{\text { Site }}$} & \multirow[b]{2}{*}{$\mathrm{pH}$} & \multirow[b]{2}{*}{$\mathrm{EC}\left(\mathrm{dS} \cdot \mathrm{m}^{-1}\right)^{\mathrm{z}}$} & \multirow[b]{2}{*}{$\mathrm{OM}(\%)$} & $\mathrm{NO}_{3}-\mathrm{N}^{\mathrm{y}}$ & $\mathbf{P}$ & $\mathbf{K}$ & $\mathrm{Zn}$ & $\mathrm{Fe}$ & Mn & $\mathbf{C u}$ \\
\hline & & & & \multicolumn{7}{|c|}{ - } \\
\hline Tunnel 4 (2013) & 7.3 & 0.5 & 1.5 & 10.1 & 28 & 419 & 4.4 & 10.7 & 6.7 & 3.6 \\
\hline Tunnel $6(2013)$ & 7.4 & 0.6 & 2.1 & 9.4 & 39 & 562 & 5.4 & 9.8 & 7.5 & 4.7 \\
\hline Field $(2014)$ & 8.1 & 0.69 & 2.8 & 8.8 & 26 & 457 & 1.5 & 6.2 & 3.1 & 1.3 \\
\hline
\end{tabular}

${ }^{\mathrm{z}} 1 \mathrm{dS} \cdot \mathrm{m}^{-1}=1 \mathrm{mmho} / \mathrm{cm}$.

${ }^{y} \mathrm{NO}_{3}-\mathrm{N}=$ nitrate nitrogen, $\mathrm{P}=$ phosphorus, $\mathrm{K}=$ potassium, $\mathrm{Zn}=\mathrm{zinc}, \mathrm{Fe}=$ iron, $\mathrm{Mn}=$ manganese, $\mathrm{Cu}=\mathrm{copper} ; \mathrm{lmg} \cdot \mathrm{kg}^{-1}=1 \mathrm{ppm}$.

Table 2. Seeding, transplanting, and harvest dates for kale in organic fertility trials in high tunnels in 2013 and in field in 2014 at Colorado State University, Fort Collins.

\begin{tabular}{lccr}
\hline Yr & $\begin{array}{c}\text { Seeding date } \\
\text { (greenhouse) }\end{array}$ & $\begin{array}{c}\text { Transplant } \\
\text { date } \\
\text { (to field) }\end{array}$ & $\begin{array}{c}\text { Harvest } \\
\text { dates }\end{array}$ \\
\hline 2013 & 3 May & 23 May & 9 July \\
& & 13 Aug. \\
& & & 15 Sept. \\
2014 & 30 Apr. & 15 May & 14 Oct. \\
& & & 29 July \\
& & & 25 Aug. \\
\hline
\end{tabular}

Table 3. Measured nutrient concentrations of three fertilizers (cyano-fertilizer, alfalfa meal, fish emulsion) used to study organic fertilizer comparison on growth and nutrient content of three kale cultivars (Winterbor, Red Russian, and Dinosaur). Nitrogen $(\mathrm{N})$ was analyzed by a carbon and nitrogen elemental analyzer and the other nutrients were analyzed by inductively coupled plasma atomic emission spectroscopy after acid digestion.

\begin{tabular}{|c|c|c|c|c|c|c|c|}
\hline \multirow[b]{2}{*}{ Fertilizer } & \multirow[b]{2}{*}{$\mathbf{N}(\%)$} & $\mathbf{P}^{\mathrm{z}}$ & $\mathbf{K}$ & $\mathrm{Ca}$ & Mg & $\mathrm{Fe}$ & $\mathrm{Zn}$ \\
\hline & & \multicolumn{6}{|c|}{ (n- } \\
\hline Cyano-fertilizer ${ }^{y}$ & 0.189 & 5.78 & $<0.1$ & 9.68 & 17.9 & 6.19 & $<0.1$ \\
\hline Alfalfa meal $(2.5 \mathrm{~N}-0.2 \mathrm{P}-2 \mathrm{~K})$ & 3.09 & 5,140 & 55,200 & 25,400 & 11,400 & 663 & 17.8 \\
\hline $\begin{array}{l}\text { Fish emulsion }(2 \mathrm{~N}-1.7 \mathrm{P}- \\
0.8 \mathrm{~K})\end{array}$ & 2.38 & 20,800 & 5,540 & 3,910 & 720 & 37.8 & 4.38 \\
\hline
\end{tabular}

${ }^{\mathrm{z}} \mathrm{P}=$ phosphorus, $\mathrm{K}=$ potassium, $\mathrm{Ca}=$ calcium, $\mathrm{Mg}=$ magnesium, $\mathrm{Fe}=$ iron, $\mathrm{Zn}=$ zinc; $1 \mathrm{mg} \cdot \mathrm{kg}^{-1}=1 \mathrm{ppm}$. ${ }^{\mathrm{y}}$ Produced on-site, thus no fertilizer grade was available.

sativa) paddies as early as 1973 (Roger and Kulasooriya, 1980), but they were presumably present and provided $\mathrm{N}$ to the paddies for centuries before. On-farm production of cyano-fertilizer cuts out the costs associated with relying on off-farm sources; and by using a biological process outside of the soil, the farmer can control application timing and $\mathrm{N}$ rates. A greenhouse study by Sukor (2013) found $\mathrm{N}$ availability in solid cyanobacteria to be $6 \%$ greater than compost, but $9 \%$ less available than fish emulsion when used on clayey soils, with similar results on sandy soils. Sukor (2013) also showed that cyano-fertilizer increased lettuce (Lactuca sativa) yields by $58 \%$ when compared with composted manure. Research is underway to improve $\mathrm{N}$ fixation efficiency and economic feasibility of cyano-fertilizer.

Kale (Brassica oleracea and Brassica napus) is one of the most widely consumed vegetables in the United States along with others in the species B. oleracea [cauliflower, broccoli, cabbage (Thomson et al., 2007)]. In 1993, Dangler and Wood found optimal yield increases in kale cultivars at $\mathrm{N}$ rates of $112 \mathrm{~kg} \cdot \mathrm{ha}^{-1}$ when grown in the Norfolk-Orangeburg loamy sand of Alabama. These rates produced yields of 9.9 to $14.9 \mathrm{t} \cdot \mathrm{ha}^{-1}$, depending on in-row spacing. In terms of human nutrition, these cruciferous vegetables are often high in iron (Fe) and zinc $(\mathrm{Zn})$, micronutrients important in reducing oxidative stress, which is highly correlated with chronic disease reduction (Tomey et al., 2007). These micronutrients also act as cofactors for antioxidant enzymes long known for their importance in human health. $\mathrm{Zn}$ plays an important role in blood coagulation and in protecting DNA from modifications, thus decreasing the risk of cancer (Messias et al., 2015) and has also been found to increase plant tolerance to adverse environments (Cakmak, 2008). While there are many studies focusing on $\mathrm{Zn}$ composition in cereal grains, there is a growing interest in leafy greens as a substantial dietary source of $\mathrm{Zn}$ (Broadley et al., 2010). Deficiencies in micronutrients such as Fe can cause anemia, a state of low red blood cells, which limits the movement of oxygen within the body. Thirty-three percent of women of reproductive age suffer from anemia worldwide (Food and Agriculture Organization of the United Nations, 2017). The accumulation of these micronutrients in edible plant tissue can vary based on the type and quantity of fertilizer applied (Cakmak, 2008). Nitrogen fertilizers have shown positive impacts on a plant's ability to accumulate $\mathrm{Fe}$ and $\mathrm{Zn}$; increased $\mathrm{N}$ rates can elevate Fe and $\mathrm{Zn}$ concentration in leaf tissue (Aciksoz et al., 2011). As consumer interest in nutritionally dense foods increases, kale may be an important crop to which to turn.

The objective of this study was to compare the effects of different organic fertilizers on yield and nutrient content 
Table 4. Nitrogen (N) application rates for each research site and fertilizer treatment (alfalfa meal, fish emulsion, cyanofertilizer). Research sites were used to study organic fertilizer comparison on growth and nutrient content of kale in high tunnels (Tunnel 4, Tunnel 5, and Tunnel 6) in 2013 and in the field in 2014 at Colorado State University, Fort Collins.

\begin{tabular}{|c|c|c|c|c|}
\hline \multirow[b]{2}{*}{ Site } & $\mathrm{N}$ application rate & Alfalfa meal applied ${ }^{\mathrm{z}}$ & Fish emulsion applied $^{\mathrm{z}}$ & Cyano-fertilizer applied ${ }^{\mathrm{z}}$ \\
\hline & \multicolumn{2}{|c|}{$(\mathrm{lb} / \text { acre })^{\mathrm{y}}$} & \multicolumn{2}{|c|}{$(\text { gal/acre })^{\mathrm{y}}$} \\
\hline Tunnel 4 (2013) & 79.8 & 3,190 & 367 & 229,000 \\
\hline Tunnel 6 (2013) & 81.2 & 3,250 & 374 & 228,000 \\
\hline Field $(2014)$ & 82.4 & 3,300 & 379 & 243,000 \\
\hline
\end{tabular}

${ }^{\mathrm{z}}$ Applications of alfalfa meal and fish fertilizer were based on percent $\mathrm{N}$ reported on the fertilizer labels, not measured $\mathrm{N}$ concentrations. Applications of cyano-fertilizer estimated based on average $0.003 \% \mathrm{~N}$ concentration.

${ }^{\mathrm{y}} \mathrm{l} \mathrm{lb} / \mathrm{acre}=1.1209 \mathrm{~kg} \cdot \mathrm{ha}^{-1}, \mathrm{l} \mathrm{gal} / \mathrm{acre}=9.3540 \mathrm{~L} \cdot \mathrm{ha}^{-1}$.

of three cultivars of kale. Kale was chosen for its long growing season (frost tolerance) and continuous need for a steady supply of $\mathrm{N}$ for plant growth.

\section{Materials and methods}

Location. Field experiments were carried out at the Colorado State University (CSU) Agriculture Research, Development and Education Center (ARDEC) in Fort Collins. ARDEC has 10 acres of certified organic land with sandy clay soils classified as a fine, smectitic, mesic Aridic Argiustoll of the Nunn series (U.S. Department of Agriculture, 2014). The site also includes six high tunnels, $20 \times 50 \mathrm{ft}$ each, that are metal framed with insect screen covering and greenhouse plastic roll-up entrance doors. The experiment was carried out in three adjacent tunnels in 2013, which are referred to in this study as high tunnels 4,5 , and 6 (three replicates). In 2014, the experiment was moved just north of the high tunnels into the open field to prevent repeating a fertilizer study in the same location 2 years in a row. Soil samples, collected in many spots and bulked together for a single sample representing each unique growing environment (Table 1 ), were collected to a depth of 12 inches from each tunnel on 2 Nov. 2012 for the 2013 growing season and from the field on 25 Feb. 2014 for the 2014 growing season. The high tunnel soil samples were analyzed separately as they had differing uses in years prior, while the field samples were combined for analysis because the field had been uniformly used in years prior. Soil samples were analyzed by the Soil, Water, and Plant Testing Laboratory at CSU (Table 1).

Kale Cultivars. Organic seeds of cultivars Winterbor, Red Russian,

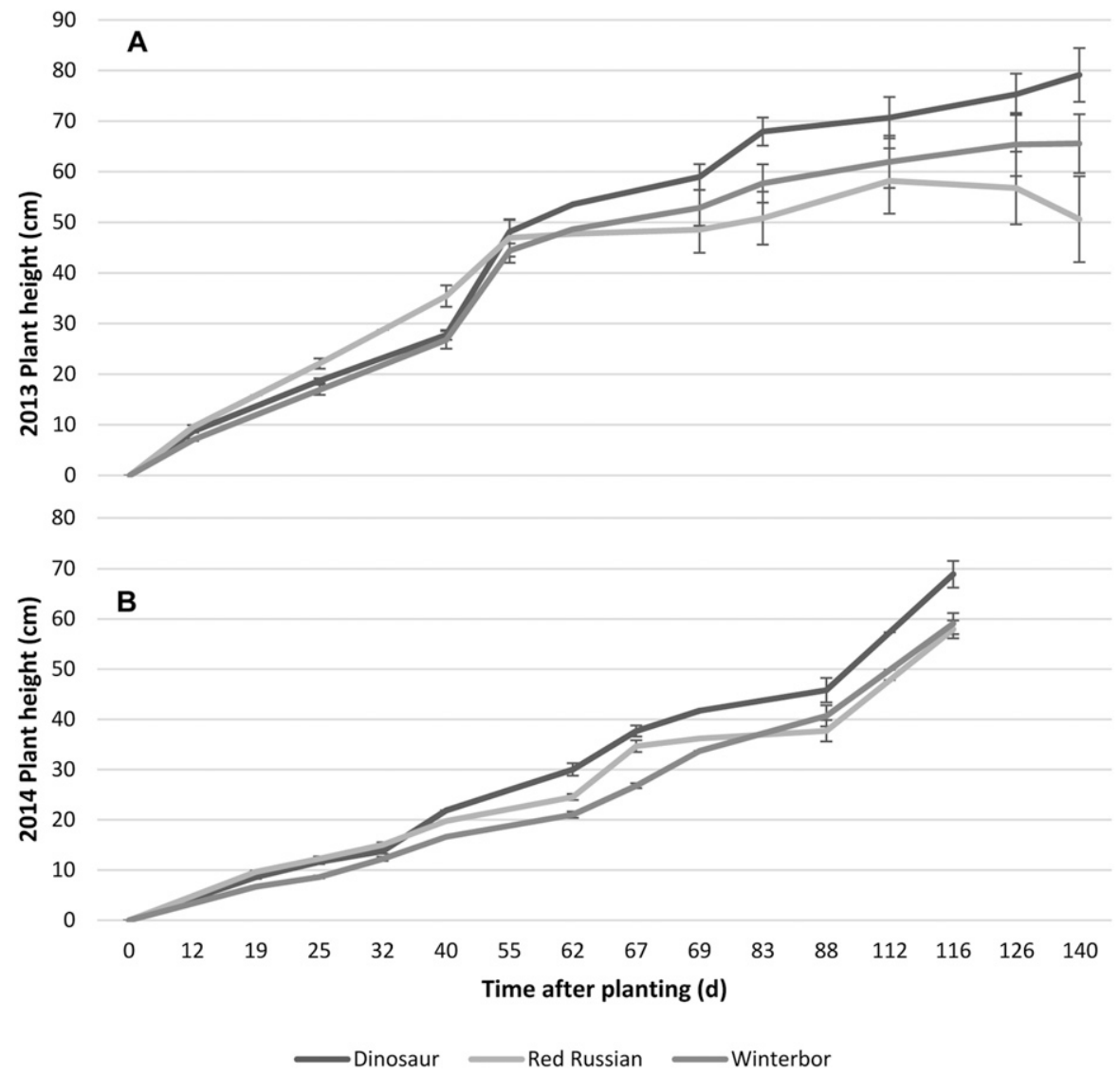

Fig. 1. Plant height of three kale cultivars (Winterbor, Red Russian, Dinosaur) as a function of days after planting averaged across three fertilizer treatments (alfalfa meal, fish emulsion, cyano-fertilizer) throughout the growing season at Colorado State University, Fort Collins in 2013 (A) and 2014 (B). Bars represent the standard error of the mean for each sample group; $1 \mathrm{~cm}=0.3937$ inch.

and Dinosaur (also known as Toscano or Lacinato) were purchased from Johnny's Selected Seeds (Winslow, ME) in 2013 and 2014. All seeds were started at W.D. Holley Plant Environmental Research Center's greenhouse facility on the CSU campus using Sunshine Organic potting medium (Sun Gro Horticulture, Agawam, MA). All kale cultivars were seeded into 72 -cell plug trays, then placed on the misting benches, and remained there until being transplanted into the field (Table 2).

EXPERIMENTAL DESIGN. In 2013, each high tunnel served as a replicate containing whole plots of three fertilizer treatments and split plots of three kale cultivars. Each split plot contained 18 plants. The kale was planted in two rows per 2 - $\mathrm{ft}$ bed with an inrow spacing of 14 inches, a betweenrow spacing of 12 inches, and $3-\mathrm{ft}$ alleys between beds. In 2014, the 
same design and spacing were used in the field by creating three side-by-side blocks instead of three high tunnels.

BED PREPARATION AND FERTILIZER Treatments. Three $2 \times 40-\mathrm{ft}$ beds were hand cultivated 12 inches deep using a 20 -inch-wide broad fork in each of three high tunnels in 2013. In 2014 , the field was disked and rototilled before setting up the same bed spacing. In each high tunnel or block, the three beds received different fertilizer treatments. Two lines of drip tape were stretched across each bed spaced 10 inches apart with a double header (mainline) in each tunnel. The drip tape used was John Deere (Moline, IL) 15-mil with 8inch-spaced emitters and an output of $0.6 \mathrm{gal} / \mathrm{min}$ per $100 \mathrm{ft}$.

The fertilizers compared in this study were alfalfa meal $(3.09 \% \mathrm{~N})$, fish emulsion [Neptune's Harvest Hydrolyzed Fish Fertilizer $(2.39 \% \mathrm{~N}$ calculated to $0.217 \mathrm{lb} / \mathrm{gal} \mathrm{N}$ based on product density)], and cyano-fertilizer $(0.189 \% \mathrm{~N})$ (Table 3$)$. Fertilizers were applied at rates based on soil tests, and a target soil $\mathrm{NO}_{3}-\mathrm{N}$ concentration of $100 \mathrm{lb} /$ acre for a 6-inch depth. This calculation was done by multiplying reported $\mathrm{NO}_{3}-\mathrm{N}$ in milligrams per kilogram by two and that was subtracted from the target $100 \mathrm{lb} /$ acre. For example, Tunnel 4 had 10.1 $\mathrm{mg} \cdot \mathrm{kg}^{-1} \mathrm{~N}$; this was multiplied by two to estimate $20.2 \mathrm{lb} /$ acre $\mathrm{N}$ and subtracted from 100 for a target application of $79.8 \mathrm{lb} /$ acre. $\mathrm{N}$ application rate is shown for each high tunnel and field in Table 4. Samples of all fertilizers were sent to the Soil, Water, and Plant Testing Laboratory at CSU and analyzed for $\mathrm{N}$, phosphorus $(\mathrm{P})$, potassium $(\mathrm{K})$, calcium $(\mathrm{Ca})$, magnesium $(\mathrm{Mg}), \mathrm{Fe}$, and $\mathrm{Zn}$ (Table 3 ). Both the fish fertilizer and cyanofertilizer were applied in liquid form, while the alfalfa meal was a dry powder and was applied by even dispersal over the treatment rows by hand and incorporated into the top 6 inches using a hoe before planting. For this study the $\mathrm{N}$-fixing cyanobacteria was cultured from local soils and inoculated into nutrient-supplemented raceways. The cyanobacteria populations grew, as did the concentration of $\mathrm{N}$ in the water as the bacteria fixed the $\mathrm{N}_{2}$ gas from the air and assimilated it into their cells (Barminski et al., 2016). After fertigation, the alfalfa meal treatment plots were watered for an equivalent amount of time to balance-out overall water application to the plots.

IRRIGATION AND FERTIGATION. Irrigation was applied three times weekly, adjusted for rainfall, and cut off the night before any liquid fertilizer treatments. Cyano-fertilizer was pumped directly from production raceways into the drip irrigation system using a sump pump with no filtration. Because the $\mathrm{N}$ concentration was variable for cyano-fertilizer throughout the season, $\mathrm{N}$ was measured before each application and the application rates were adjusted accordingly.

In 2013, fish fertilizer was mixed into watering troughs and applied directly into the drip irrigation using the same pump after being flushed with city water; while in 2014, fish fertilizer was applied using a venturi siphon. Each treatment row had individual control valves allowing for uniform application to all treatment plots.

Cultural practices. Weeding was done by hand throughout the season. In both 2013 and 2014, two applications of BT (Bacillus thuringiensis) were made to control cabbage worms (Pieris rapae).

Measurements. Weekly data were collected on plant height. There were four harvests during the growing season in 2013 and three harvests
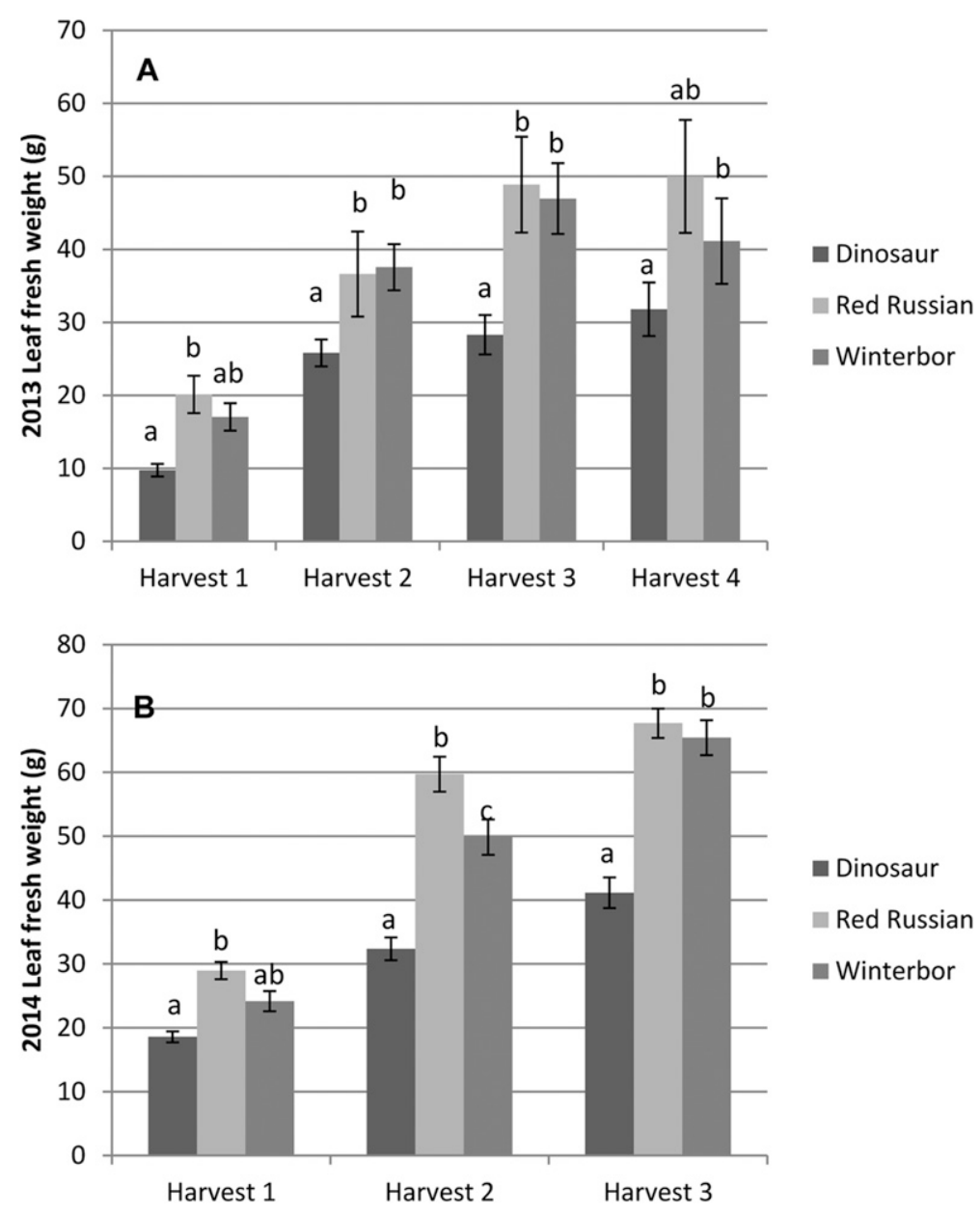

Fig. 2. Individual leaf weight of three kale cultivars (Winterbor, Red Russian, Dinosaur) at different harvest times averaged across three fertilizer treatments (alfalfa meal, fish emulsion, cyano-fertilizer) at Colorado State University, Fort Collins in 2013 (A) and 2014 (B). Cultivars within harvest with a common letter are not significantly different $(P<0.05)$. All probability values were determined using PROC MIXED from SAS (version 9.3; SAS Institute, Cary, NC), and statistical differences within interactions were found using the slice statement. Each slice was determined after analyzing the type 3 tests of fixed effects; $1 \mathbf{g}=$ $0.0353 \mathrm{oz}$. 
during the 2014 growing season (Table 4 ). Due to an early hailstorm on 22 June 2014, the first harvest was delayed. During each harvest, two healthy (without noticeable disease or insect damage, and lacking necrosis and chlorosis), mature (but not senescing) leaves were removed from 10 predetermined, representative plants in the center of each sub-plot. Individual leaf weights were measured, and average leaf area was determined using an area meter (LI-3100; LICOR, Lincoln, NE). Ten leaves from each subplot were then dried in an oven set to $70^{\circ} \mathrm{C}$ for $72 \mathrm{~h}$, ground in a plant grinder, and sent to Ward Laboratories (Kearney, NE) for $\mathrm{N}$, $\mathrm{Fe}$, and $\mathrm{Zn}$ analysis. Total $\mathrm{N}$ was measured using methods described by Peters et al. (2003), and Fe and $\mathrm{Zn}$ were analyzed in acid digests of the plant samples (Johnson and Ulrich, 1959).

Postharvest. After the final harvest, all sub-plots were soil sampled to a 6-inch depth and air-dried for 2 weeks in a walk-in cooler at ARDEC to minimize $\mathrm{NH}_{4}$ volatilization during drying. Once dried, $\mathrm{NO}_{3}-\mathrm{N}$ and $\mathrm{NH}_{4}-\mathrm{N}$ was extracted using $2 \mathrm{M}$ potassium chloride $(\mathrm{KCl})$ at a $1: 10$ ratio ( $2 \mathrm{~g}$ of soil in $20 \mathrm{~mL}$ of $2 \mathrm{M} \mathrm{KCl}$ ). After shaking, the samples were filtered and analyzed at CSU's EcoCore Analytical Services for automated colorimetric analysis of $\mathrm{NH}_{4}-\mathrm{N}$ and $\mathrm{NO}_{3}-\mathrm{N}$ concentrations using an Alpkem autoanalyzer from OI Analytical in College Station, TX (Keeney and Nelson, 1982).

Statistical analysis. All data were processed using SAS (version 9.3; SAS Institute, Cary, NC). All $P$ values $(P<0.05)$ were determined using PROC MIXED, and statistical differences within interactions were found using the slice statement. Cultivar, treatments, and harvest were fixed, and the blocks were treated as random. Each slice was determined after analyzing the type 3 tests of fixed effects.

\section{Results}

Plant height. There were no significant differences in plant height among fertilizer treatments. Differences were found among cultivars $(P=0.002$ in $2013, P<0.001$ in $2014)$ and among measurement dates $(P<0.0001)$. There was also a significant interaction between cultivar and measurement dates $(P<0.0001)$.

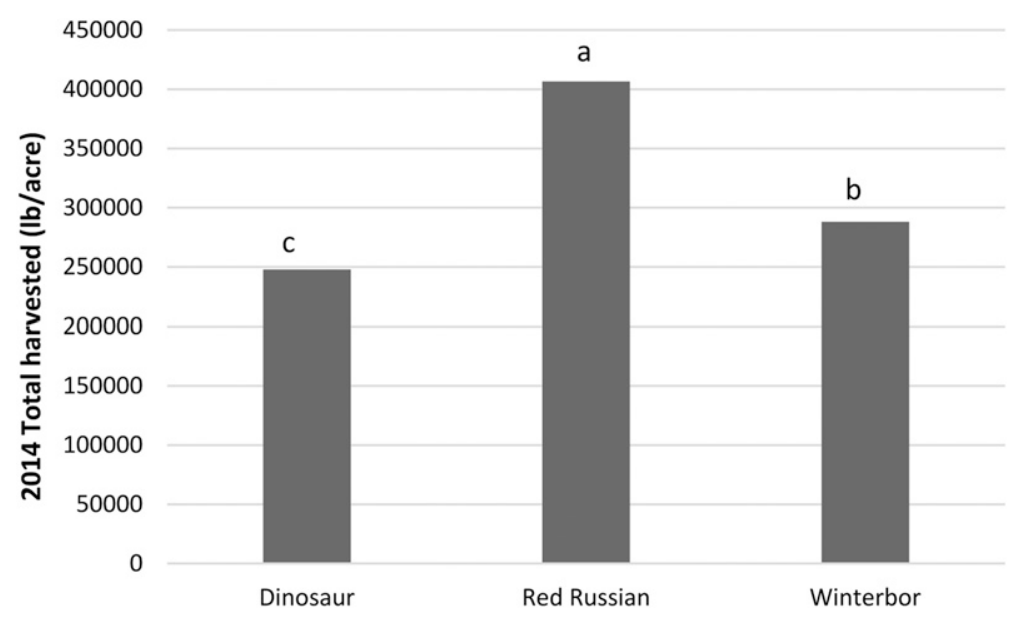

Fig. 3. Total harvest for three kale cultivars (Winterbor, Red Russian, Dinosaur) grown in the field at Colorado State University, Fort Collins in 2014 averaged across three fertilizer treatments (alfalfa meal, fish emulsion, cyano-fertilizer). This is based on $2-\mathrm{ft}(0.6 \mathrm{~m})$ beds with $3-\mathrm{ft}(0.9 \mathrm{~m})$ alleys, two rows on each bed with a 14 inch $(35.6 \mathrm{~cm})$ within-row spacing; $1 \mathrm{lb} / \mathrm{acre}=1.1209 \mathrm{~kg} \cdot \mathrm{ha}^{-1}$.
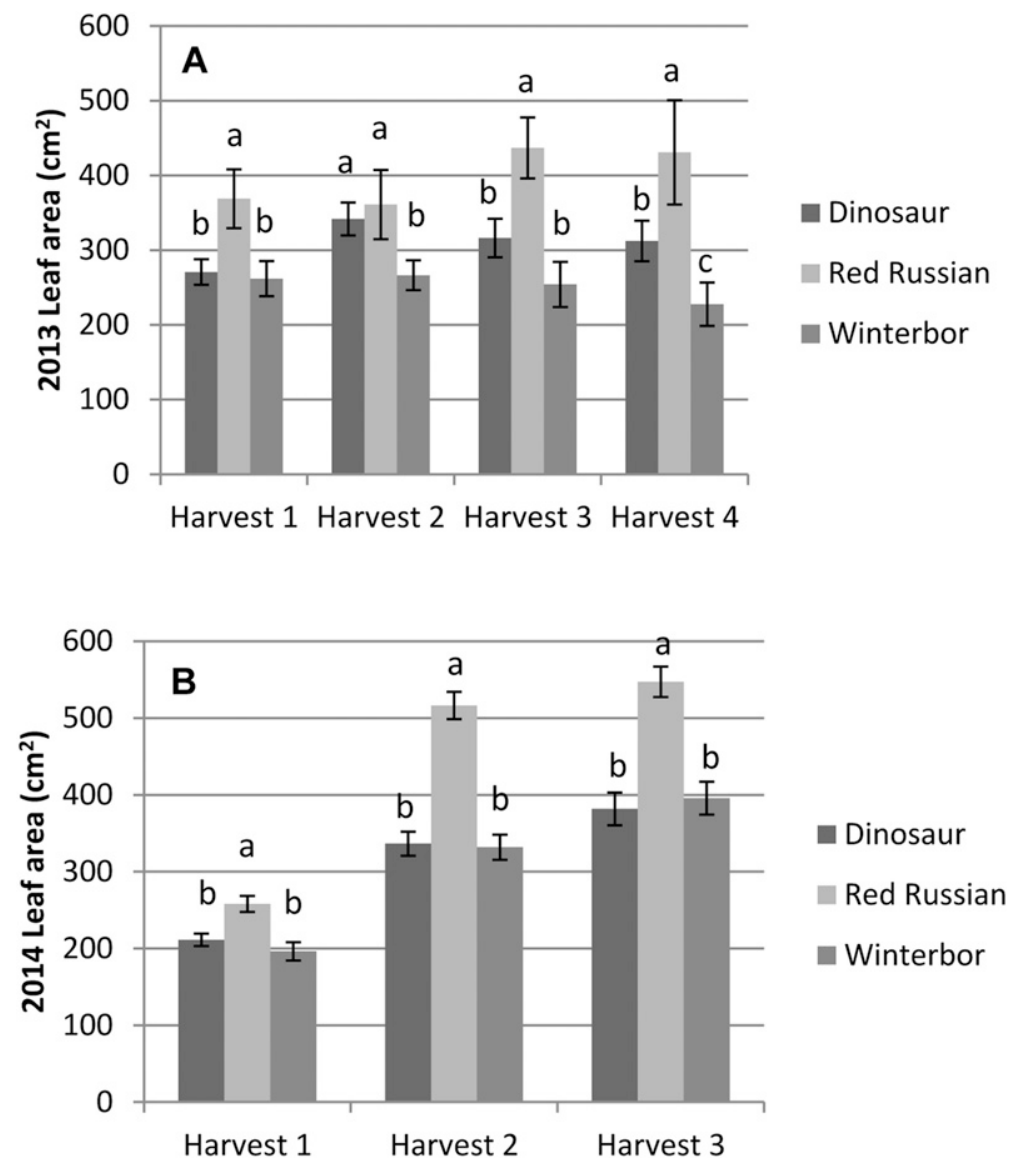

Fig. 4. Individual leaf area of three kale cultivars (Winterbor, Red Russian, Dinosaur) at harvest times averaged across three fertilizer treatments (alfalfa meal, fish emulsion, and cyano-fertilizer) at Colorado State University, Fort Collins in 2013 (A) and 2014 (B). Bars represent SE for each sample group. All probability values $(P<0.05)$ were determined using PROC MIXED by SAS (version 9.3; SAS Institute, Cary, NC), and statistical differences within interactions were found using the slice statement. Each slice was determined after analyzing the type 3 tests of fixed effects; $1 \mathrm{~cm}^{2}=0.1550$ inch $^{2}$. 
This interaction could be explained by a difference in growth patterns of both the stems and leaves among cultivars. In both years, 'Dinosaur' was consistently the tallest cultivar $50 \mathrm{~d}$ after planting, while Red Russian and Winterbor were usually similar in height (Fig. 1). 'Dinosaur' kale was very upright and straight, with long, lean leaves growing vertically above the stem, while the other cultivars had a more horizontal growth habit.

LEAF WEIGHT. Individual leaf weight showed no difference among fertilizer treatments $(P=0.586$ in $2013, P=0.43$ in 2014). However, there were differences in leaf weight among cultivars in both 2013 and 2014 (Fig. 2). In addition, as the season progressed, the leaves accumulated more mass, resulting in statistically significant differences. Dinosaur kale has a smaller, narrower leaf structure that probably accounts for the lower leaf weight of that cultivar. Total yield (weight of all marketable leaves from plants) was also recorded in 2014. Fertilizer treatments had no yield effect, but 'Red Russian' yielded significantly higher than 'Winterbor', and 'Winterbor' yielded more than 'Dinosaur' (Fig. 3).

LEAF AREA. Leaf area was unaffected by fertilizer treatment $(P=$ 0.438 in $2013, P=0.288$ in 2014), but cultivars showed differences in leaf area $(P<0.0001)$ due to their different leaf morphologies (Fig. 4). 'Red Russian' and 'Dinosaur' both have flat, easy-to-scan leaf surfaces. 'Winterbor's' frilled texture made it difficult to scan a 2D image of the total surface area, leading to lower leaf-area measurements. 'Red Russian' had higher individual leaf area than 'Dinosaur' or 'Winterbor'. In 2014 , leaf area increased with harvest date $(P<0.001)$, although there were no differences in harvest dates in 2013. This could be due to the difference in high tunnel and open field growing conditions.

LEAF N. There was no difference in leaf $\mathrm{N}$ among fertilizer treatments in either year $(P=0.728$ in $2013, P=$ 0.628 in 2014). However, there were differences in leaf $\mathrm{N}$ among cultivars (Fig. 5). In 2013, 'Red Russian' had the highest leaf N concentrations, but in 2014, 'Dinosaur' had the highest leaf $\mathrm{N}$ concentrations. In addition, an interaction between kale cultivar and harvest date $(P=0.02)$ was observed in leaf $\mathrm{N}$ concentration in 2013; in the first harvest, there was no cultivar effect, but in the later harvest, Red Russian was significantly higher (Fig. 5).

LEAF Fe. Iron and $\mathrm{Zn}$ were only analyzed on 'Dinosaur' kale in 2013 as a sample group before determining research value and expanding analysis to all cultivars in 2014 (Fig. 6). Therefore, no cultivar effects were evaluated until 2014. There was no difference in leaf Fe among fertilizer treatments either year $(P=0.141$ in $2013, P=0.384$ in 2014). The only difference observed in Fe concentrations was among harvests $(P<$ $0.0001)$. However, when treatments were analyzed by harvest, cyano-fertilizer had a significantly higher Fe concentration than alfalfa meal in the first harvest in $2013(P=0.001)$, but later harvests had lower Fe concentrations and no differences among fertilizer treatments. Interestingly, $\mathrm{Fe}$ concentration decreased over the growing season in 2013, but not in 2014 (Fig. 6), perhaps due to the higher soil $\mathrm{pH}$ and lower available soil $\mathrm{Fe}$ concentration in the open field (Table 1). Finally, the only cultivar difference in 2014 occurred in the first harvest, and Dinosaur had the highest leaf Fe concentration.

LeAF $\mathbf{Z}_{N}$. There were also no effects of fertilizer treatments on leaf Zn concentration $(P=0.818$ in 2013,
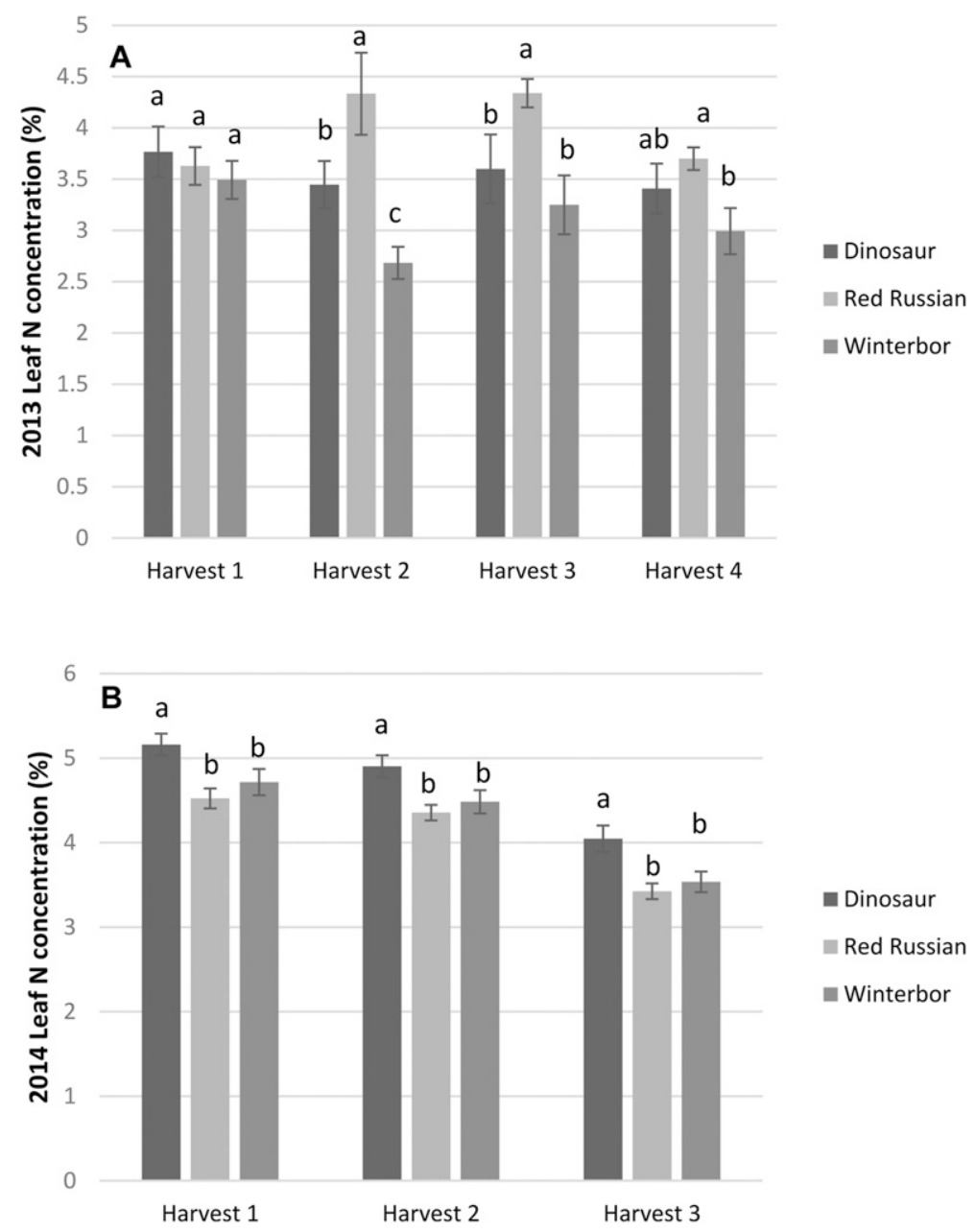

Fig. 5. Leaf nitrogen $(\mathrm{N})$ concentration in three kale cultivars (Winterbor, Red Russian, and Dinosaur) at different harvest times averaged across three fertilizer treatments (alfalfa meal, fish emulsion, and cyano-fertilizer) at Colorado State University, Fort Collins in 2013 (A) and 2014 (B). Cultivars within harvest with a common letter are not significantly different. Significance in PROC MIXED $(P<$ 0.05 ) by SAS (version 9.3; SAS Institute, Cary, NC). All probability values were determined using PROC MIXED, and statistical differences within interactions were found using the slice statement. Each slice was determined after analyzing the type 3 tests of fixed effects. 

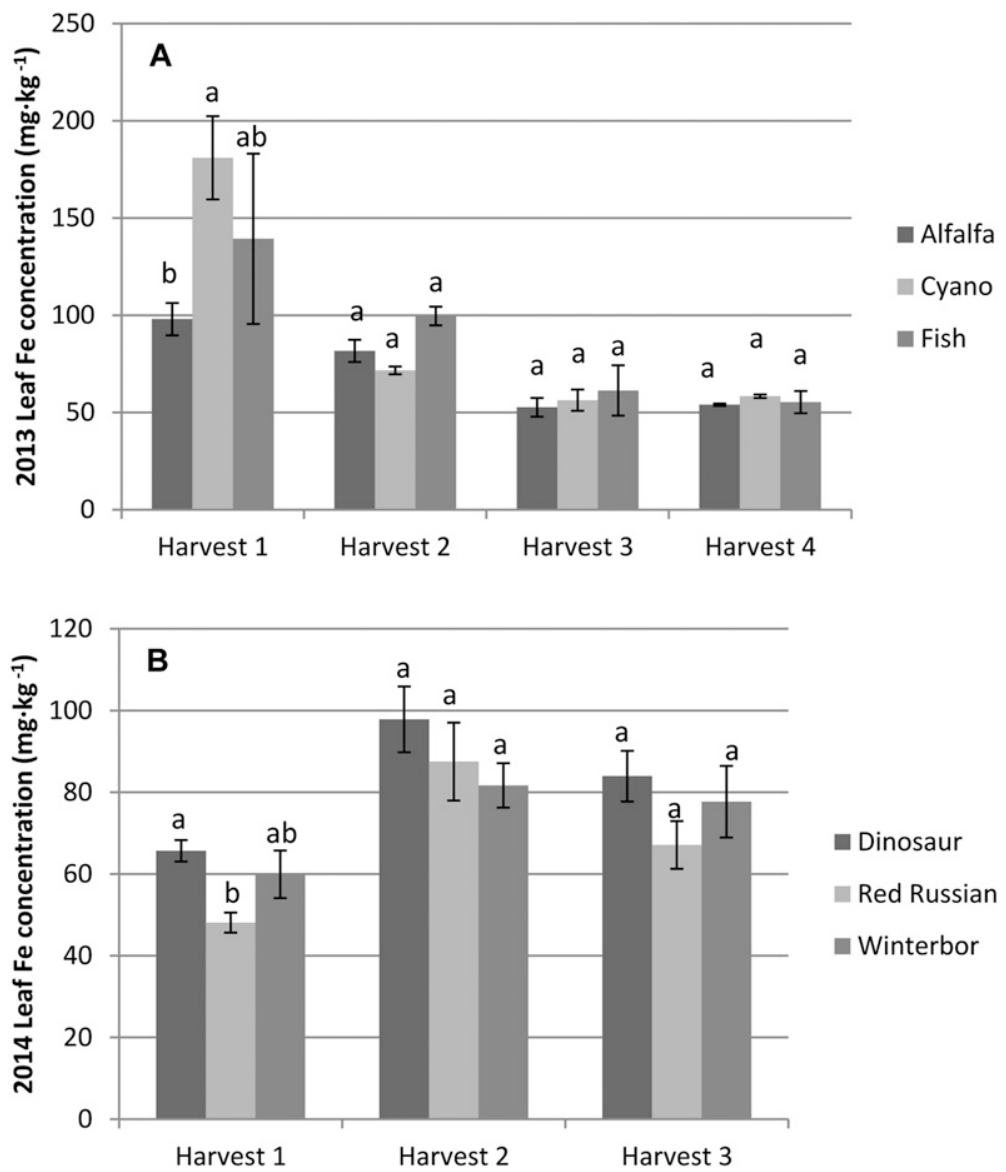

Fig. 6. Leaf irin ( $\mathrm{Fe})$ concentration in 'Dinosaur' kale as influenced by harvest time and fertilizer treatment (alfalfa meal, fish emulsion, or cyano-fertilizer) at Colorado State University, Fort Collins in 2013 (A), and by harvest time and cultivar averaged across fertilizer treatments in 2014 (B). Cultivars within harvest with a common letter are not significantly different. Significance in PROC MIXED $(P<0.05)$ by SAS (version 9.3; SAS Institute, Cary, NC). All probability values were determined using PROC MIXED, and statistical differences within interactions were found using the slice statement. Each slice was determined after analyzing the type 3 tests of fixed effects; $1 \mathrm{mg} \cdot \mathrm{kg}^{-1}=1 \mathrm{ppm}$.

$P=0.937$ in 2014). In 2013, there was no effect of harvest date $(P=$ $0.681)$, but in 2014 a harvest effect $(P<0.001)$ was found due to a dramatic reduction in leaf $\mathrm{Zn}$ concentration in 'Red Russian' kale from the first harvest to the second harvest (Fig. 7 ). In addition, 'Winterbor' had the lowest leaf $\mathrm{Zn}$ concentration at all harvest times.

Residual soil N. Fertilizer treatment had no effect on postharvest soil $\mathrm{NO}_{3}-\mathrm{N}(P=0.531$ in $2013, P=0.7$ in $2014)$ or $\mathrm{NH}_{4}-\mathrm{N}(P=0.165$ in 2013, $P=0.936$ in 2014).

\section{Discussion}

Plant height. The plant height results are related to plant architecture. The plant structures of 'Dinosaur' and 'Winterbor' are very upright with a distinct vertical central stem; but unlike 'Winterbor', with its horizontal leaves, 'Dinosaur's' leaves tend to grow vertically, which contributes to 'Dinosaur's' greater height. 'Red Russian', a short plant with extreme branching at the base of the stem, also received noticeable aphid damage midseason, which may have contributed to further reductions in height. No aphid damage was observed on the other cultivars. There were no fertilizer treatment differences in plant height.

Leaf WEIGHT. Measuring leaf weight in kale is primarily useful for leaves that are sold by weight (fresh, processed, and frozen) as opposed to fresh market numbered bunches. The only difference was found among cultivars and was primarily due to leaf morphology. 'Dinosaur' kale might sell well in numbered bunches, while the heavier cultivars, Winterbor and Red Russian, would be a better choice for growers interested in selling kale by weight.

LeAf AREA. Supplemental N application has been shown to increase kale leaf area (Balcau et al., 2012). In contrast to leaf weight, leaf area is useful for growers interested in selling kale by the bunch. If stems are counted into bunches, a leaf with a higher area will appear to be a larger bunch, thus enhancing consumer appeal. However, two-dimensional leaf area measurements, as taken in this study, may not be most useful for some cultivars of kale. 'Red Russian' has large, flat leaves, making leaf-area measurement easier, but insect damage more apparent. 'Winterbor' had the lowest leaf area on average, yet its frilled, three-dimensional texture leads to fuller bunches that cannot be predicted from leaf area alone. 'Winterbor's' leaf shape hid insect damage well, something to take into account when considering consumer appeal. While leaf area is useful in examining leaf growth within a cultivar, it proves less useful in comparing cultivars due to their innate differences.

LEAF N. Leaf N sufficiency range is reported to be 3 to $5 \%$ for kale at harvest (Maynard and Hochmuth, 2007). At Harvest 2 and Harvest 4 in 2013, 'Winterbor' dropped below the sufficient range in all fertilizer treatments. 'Winterbor' is an $\mathrm{F}_{1}$ hybrid, which may make it a heavy feeder, and it may have needed more $\mathrm{N}$ to maintain sufficient levels even though it was receiving the same fertilizer treatments as the other cultivars. 'Winterbor' may also require less $\mathrm{N}$, resulting in lower sufficiency levels. More research is needed to evaluate this; however, there may be a difference among cultivars in terms of their $\mathrm{N}$ needs. All cultivars in 2014 remained within the sufficiency range, and 2014 results often exceeded average 2013 plant $\mathrm{N}$ concentrations even though the initial soil $\mathrm{NO}_{3}-\mathrm{N}$ concentration in the open field was lower than in the high tunnels.

Leaf Fe. Adequate Fe concentration in mature kale leaves ranges from 40 to $100 \mathrm{mg} \cdot \mathrm{kg}^{-1}$ (Maynard and Hochmuth, 2007). All Fe concentrations in this study fell within this sufficiency range, and no apparent trend emerged with regards to treatments or cultivar. 

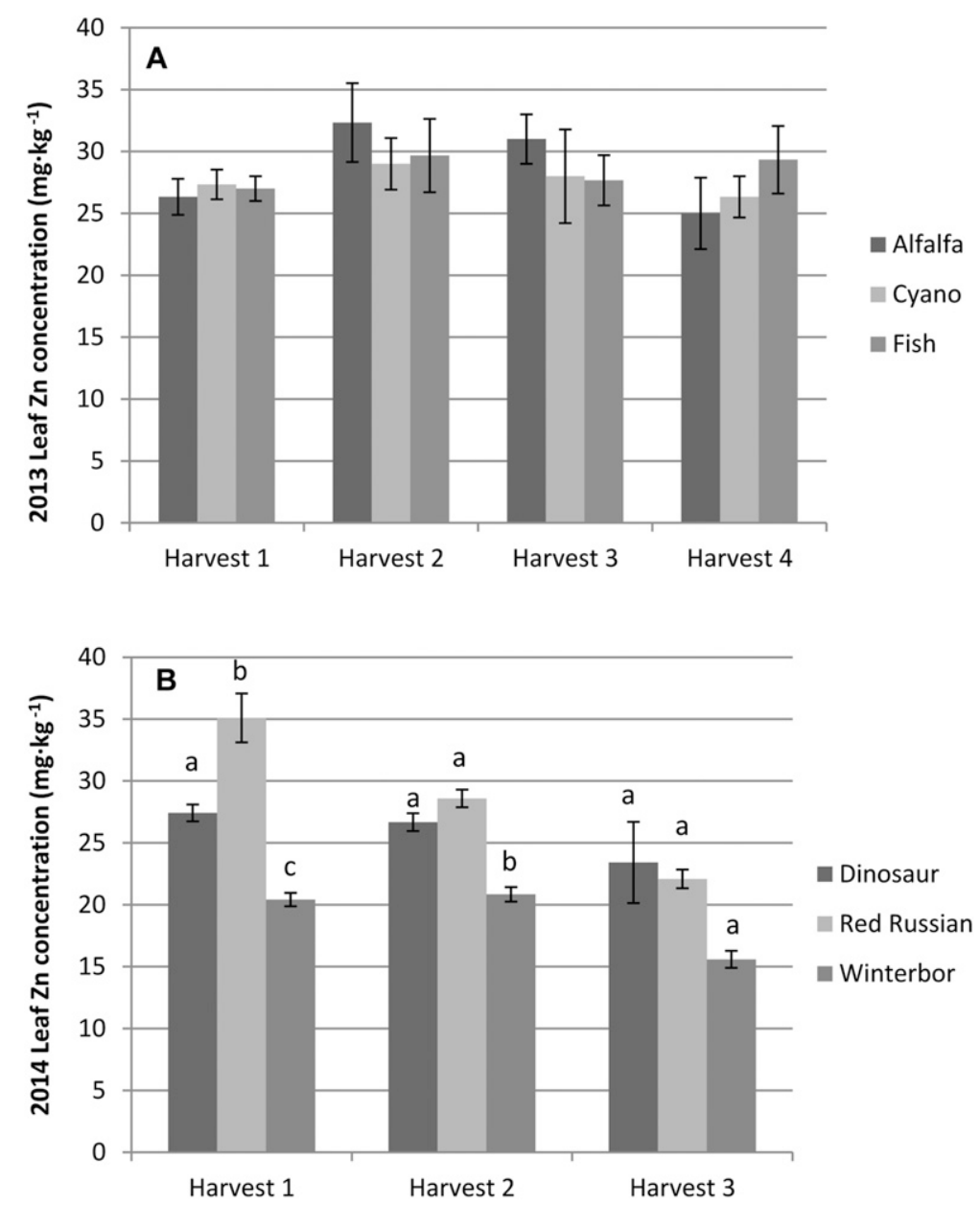

Fig. 7. Leaf zinc ( $\mathrm{Zn})$ concentration in 'Dinosaur' kale as influenced by harvest time and fertilizer treatment (alfalfa meal, fish emulsion, or cyano-fertilizer) at Colorado State University, Fort Collins in 2013 (A) and by harvest time and cultivar averaged across fertilizer treatments in 2014 (B). Cultivars within harvest with a common letter are not significantly different. There was no significant difference in 2013. Significance in PROC MIXED $(P<0.05)$ by SAS (version 9.3; SAS Institute, Cary, NC). All probability values were determined using PROC MIXED, and statistical differences within interactions were found using the slice statement. Each slice was determined after analyzing the type 3 tests of fixed effects; $1 \mathrm{mg} \cdot \mathrm{kg}^{-1}=1 \mathrm{ppm}$.

LEAF $\mathbf{Z}_{N}$. Adequate $\mathrm{Zn}$ concentrations in mature kale leaves range from 20 to $40 \mathrm{mg} \cdot \mathrm{kg}^{-1}$ (Maynard and Hochmuth, 2007). All kale in this study fell within this range, except for harvest 3 in 2014, when 'Winterbor' dropped below $20 \mathrm{mg} \cdot \mathrm{kg}^{-1}$.

Residual soIL N. Residual soil $\mathrm{NO}_{3}-\mathrm{N}$ was not statistically significant in either 2013 or 2014 . In this study, there were no statistically significant impacts of fertilizer treatment on kale growth characteristics. Cyano-fertilizer, an experimental fertilizer grown on-farm, produced the same results as fish fertilizer and alfalfa meal. Most significant differences were related to cultivar type and harvest dates-differences that could be predicted based on plant architecture and changes over time. However, cultivars and harvest times showed no interaction with fertilizer treatments. Kale cultivar choice had a larger impact on yield and plant nutrient concentrations than fertilizer choice. The cultivars demonstrated differences with respect to qualities that would interest farmers when making cultivar selections, including leaf shape and weights that one would consider when deciding to sell by the bunch or by weight.

\section{Literature cited}

Aciksoz, S.B., A. Yazici, L. Ozturk, and I. Cakmak. 2011. Biofortification of wheat and iron through soil and foliar applica- tion of nitrogen and iron fertilizers. Plant Soil 349(1):215-225.

Balcau, S.L., M. Apahidean, A. Saharia, and D. Pop. 2012. The influence of organic fertilizers concerning the growth and development of Brassica oleracea var. acehala plants. Bul. Univ. Agr. Sci. Vet. Med. 69(1):64-70

Barminski, R., H.N. Storteboom, and J.G. Davis. 2016. Development and evaluation of an organically-certifiable growth medium for cultivation of cyanobacteria. J. Appl. Phycol. 28(5):2623-2630.

Broadley, M.R., S.O. Lochlain, J.P. Hammon, H.C. Bowen, I. Cakmak, S. Eker, H. Erdem, G.J. King, and P. White. 2010. Shoot zinc $(\mathrm{Zn})$ concentration varies widely within Brassica oleracea L. and is affected by soil $\mathrm{Zn}$ and phosphorus (P) levels. J. Hort. Sci. Biotechnol. 85(5):375380 .

Cakmak, I. 2008. Enrichment of cereal grains with zinc: Agronomic or genetic biofortification? Plant Soil 302(1):1-17.

Dangler, J.M. and W.C. Wood. 1993. Nitrogen rate, cultivar, and within-row spacing affect collard yield and leaf nutrient concentration. HortScience 28:701-703.

Food and Agriculture Organization of the United Nations. 2017. The state of food security and nutrition in the world 2017. FAO, Rome, Italy.

Gaskell, M., R. Smith, J. Mitchell, S.T. Koike, C. Fouche, T. Hartz, W. Horwath, and L. Jackson. 2006. Soil fertility management for organic crops. Univ. California Publ. 7249 .

Gaskell, M. and R. Smith. 2007. Nitrogen sources for organic vegetable production. HortTechnology 17:431-441.

Hartz, T.K. and P.R. Johnstone. 2006. Nitrogen availability from high-nitrogencontaining organic fertilizers. HortTechnology 16:39-42.

Johnson, C.M. and A. Ulrich. 1959. Analytical methods for use in plant analysis. California Agr. Exp. Sta. Bul. 766.

Keeney, D.R. and D.W. Nelson. 1982. Nitrogen-inorganic forms, p. 643-698. In: R.H. Miller (ed.). Methods of soil analysis: Chemical and microbiological properties. 2nd ed. Amer. Soc. Agron.Soil Sci. Soc. Amer., Madison, WI.

Maynard, D.N. and G.J. Hochmuth. 2007. Knott's handbook for vegetable growers. 5th ed. Wiley, Hoboken, NJ.

Messias, R.S., V. Galli, S.D.D. Anjos, E. Silva, M.A. Schirmer, and C.V. Rombaldi. 2015. Micronutrient and functional compounds biofortification of maize grains. Crit. Rev. Food Sci. Nutr. 55(1):123-139. 
Peters, J., S. Combs, B. Hoskins, J. Jarman, J. Kovar, M. Watson, A. Wolf, and N. Wolf. 2003. Recommended methods of manure analysis. Univ. Wisconsin Coop. Ext. Publ. Bul. A3769.

Roger, P.A. and S.A. Kulasooriya. 1980. Blue-green algae and rice. Inti. Rice Res. Inst., Los Banos, Philippines.

Soares, J.H., Jr., D. Miller, S. Cuppett, and P. Bauerfeld. 1973. A review of the chemical and nutritive properties of condensed fish solubles. Fish Bull. 71(1):255-265.
Sukor, A. 2013. Effect of cyanobacterial fertilizers compared to commonly used organic fertilizers on nitrogen availability, lettuce growth, and nitrogen use efficiency on different soil textures. M.S. Thesis $0053 \mathrm{~N}$ 11683, Colorado State Univ., Fort Collins.

Thomson, C.A., T.R. Newton, E.J. Graver, K.A. Jackson, P.M. Reid, V.L. Hartz, E.C. Cussler, and I.A. Hakim. 2007. Cruciferous vegetable intake estimate. J. Amer. Dietetic Assn. 107(4):631-643.
Tomey, K.M., M.R. Sowers, X. Li, D.S. McConnell, S. Crawford, E.B. Gold, B. Lasley, and J.F. Randolph, Jr. 2007. Dietary fat subgroups, zinc, and vegetable components are related to urine $\mathrm{F}_{2 \mathrm{a}}$-isoprostane concentration, a measure of oxidative stress in midlife women. J. Nutr. 137(11):24122419.

U.S. Department of Agriculture. 2014. Web soil survey of Larimer County area. 1 Oct. 2014. <http://websoilsurvey.sc. egov.usda.gov/App/HomePage.htm>. 